\title{
NEUROBIOLOGICAL BASES OF ALCOHOL ADDICTION
}

\author{
Ana Matošić ${ }^{1}$, Srđan Marušić ${ }^{1}$, Branka Vidrih $^{1}$, Ana Kovak-Mufić ${ }^{1}$ and Lipa Čičin-Šain ${ }^{2}$ \\ ${ }^{1}$ Clinical Department of Psychiatry, Sestre milosrdnice University Hospital Center; ${ }^{2}$ Ruđer Bošković Institute, \\ Zagreb, Croatia
}

\begin{abstract}
SUMMARY - Alcohol addiction is a heterogeneous psychiatric disorder according to both phenotype and etiology. Difference in phenotype characteristics manifests in the manner the addiction arises, history of the alcoholic and history of drinking, comorbid disorders, and the phenomenon of abstinence difficulties. Concerning the etiology of alcoholism, the disease itself is considered to be a consequence of an interactive influence of the environment and genetic factors. Numerous researches conducted in the last decades discovered many aspects of the biochemical, cell and molecular bases of alcohol addiction, leading to a conclusion that alcoholism is, like many other addictions, a brain disease. By recognizing alcoholism as a disease which basically implies changes of the neurobiological mechanisms, as well as a clear genetic basis, it was supposed that the disease, having its basis solely in the symptomatology, is essentially heterogeneous. By trying to solve the problem of a clinically heterogeneous nature of the disease during the last fifty years, various sub-classifications of such patients have been suggested. According to Cloninger, subtypes of alcoholism differ also according to changes in the brain neurotransmission systems, i.e. it is supposed that patients suffering from alcoholism type 1 have a more pronounced dopaminergic transmission deficit, while dopaminergic transmission is not disturbed significantly in patients diagnosed with alcoholism type 2, who, however, have a significant lack of serotonergic transmission. In such a way, Cloninger actually presented the basis of the so-called neurobiological alcoholism model. Since he has connected differences in neurotransmission with differences in personality characteristics, this model is also known as the psychobiological model of alcoholism. The characteristic of alcoholism type 1 is avoiding damage (Harm Avoidance, HA) decreased dopamine transmission and increased serotonin transmission, while the significant characteristic of alcoholism type 2 is seeking for excitement (Novelty Seeking, NS), unchanged dopamine transmission and decreased serotonin transmission. These neurochemical differences among alcoholism subtypes represent the basis for a different therapy approach. Intake of alcohol changes different gene expression in the human brain. The inheritance model of alcoholism is not fully explained, however, it is considered that the disease is connected to a larger gene number included in neurotransmission, cell mechanisms and general metabolic function, with a simultaneous influence of the environment. The contribution of genetic factors is stronger in certain types of alcoholism and thus we have been confronted in the last years of alcoholism research with studies researching the connections of some alcoholism subtypes with the polymorphism phenomenon in the genes coding the synaptic proteins included in the alcoholism etiology. The primary role of monoamine oxidase (MAO) in the brain is catalysis of deamination of the oxidative neurotransmitter amines, i.e. serotonin, adrenaline, noradrenaline and dopamine. Thus, this enzyme is the key factor for maintaining cytoplasmic concentration of various neurotransmitters and for regulation of the neurotransmitting synaptic activity. Taken this
\end{abstract}

Correspondence to: Assist. Prof. Ana Matošić, MD, PhD, Clinical

Department of Psychiatry, Sestre milosrdnice University Hospi-

tal Center, Vinogradska c. 29, HR-10000,Zagreb, Croatia

E-mail: ana.matosic@kbcsm.hr

Received September 1, 2015, accepted October 12, 2015 
MAO function into consideration, MAO is the enzyme included in the etiology and pathogenesis of various neuropsychiatric and neurological disorders. The finding of the decreased platelet MAO activity in various psychiatric disorders has brought us to the assumption that this enzyme may be a constitutional/genetic indicator (trait marker) or an indicator of disease condition (state marker) in biologic psychiatry. There are only a few studies of alcohol addiction researching the connections of the MAO coding gene polymorphism and alcoholism; however, these studies are primarily related to the variable number of tandem repeats (VTNR) polymorphism in the regulatory gene region for MAO-A, considered to influence the transcription activity/functionality of the enzyme.

Key words: Alcoholism - genetics; Alcoholism - physiopathology; Genetic predisposition to disease; Monoamine oxidase - blood; Phenotype; Polymorphism, genetic

\section{Definition, Etiology and Epidemiology of Alcoholism}

Alcohol addiction is a psychiatric disorder in which long-term abuse of alcohol drinks leads to mental and bodily disorders, disturbed social relations, as well as economic difficulties. This definition was given by the World Health Organization (WHO) in Copenhagen some fifty years ago and has remained unchanged down to the present day in spite of various objections by experts related to the duration and intensity of alcohol abuse, as well as the gravity of associated disorders.

In order to set an exact diagnosis, we currently use two types of operative criteria, i.e. Diagnostic and Statistical Manual of Mental Disorders, $5^{\text {th }}$ ed. (DSM
V) and International Classification of Diseases and Relating Conditions, $10^{\text {th }}$ revision (ICD 10), whereby we differ alcohol abuse and alcohol addiction (alcohol dependence) $)^{1,2}$. In our clinical practice, it is recommended to use the ICD 10 classification, this being at the same time the WHO official classification.

As stated above, diagnostic criteria based on the mentioned classifications currently are important to set a correct diagnosis; however, alcoholism is a complex condition involving a variety of mental, physical, behavioral and cognitive changes caused by excessive intake of alcohol ${ }^{3,4}$. Considering behavioral changes, it is characteristic that our attention is drawn to drinking of alcohol in the first place while neglecting all other interests and satisfactions. Changes in the

\section{Table 1. Criteria for setting the diagnosis of dependence syndrome (according to ICD 10)}

A definitive diagnosis of dependence should usually be made only if three or more of the following have been present together at some time during the previous year:

(a) a strong desire or sense of compulsion to take the substance;

(b) difficulties in controlling substance-taking behavior in terms of its onset, termination, or levels of use;

(c) a physiological withdrawal state (see F1x.3 and F1x.4) when substance use has ceased or been reduced, as evidenced by: the characteristic withdrawal syndrome for the substance; or use of the same (or a closely related) substance with the intention of relieving or avoiding withdrawal symptoms;

(d) evidence of tolerance, such that increased doses of the psychoactive substances are required in order to achieve effects originally produced by lower doses (clear examples of this are found in alcohol- and opiate-dependent individuals who may take daily doses sufficient to incapacitate or kill nontolerant users);

(e) progressive neglect of alternative pleasures or interests because of psychoactive substance use, increased amount of time necessary to obtain or take the substance or to recover from its effects;

(f) persisting with substance use despite clear evidence of overtly harmful consequences, such as harm to the liver through excessive drinking, depressive mood states consequent to periods of heavy substance use, or drug-related impairment of cognitive functioning; efforts should be made to determine that the user was actually, or could be expected to be, aware of the nature and extent of the harm.

ICD-10 = International Statistical Classification of Diseases and Related Health Problems $10^{\text {th }}$ Revision 
central nervous system occur and manifest as a phenomenon of alcohol tolerance, signs of physical addiction and craving for alcohol, followed by loosing drinking control.

Table 1 shows diagnostic criteria according to the ICD 10 classification for setting the diagnosis of alcohol addiction. At least three of the six criteria should be present to set the clinical diagnosis of alcoholism.

Next to these diagnostic criteria, clinical practice and research also use various measuring instruments (scales) serving as assistance when evaluating the patient's profile, establishing drinking pattern, problems in persons that have not yet become addicted, etc. In most cases, we speak of shorter or longer questionnaires filled in either by the physician or by the patient himself/herself. There are more than 100 such questionnaires, e.g., Alcohol Use Disorders Identification Test (AUDIT), Michigan Alcohol Screening Test (MAST), Brief Drinker Profile (BDP), Severity of Alcohol Dependence Questionnaire (SADQ), Short Alcohol Dependent Data (SADD), and others.

Accordingly, one should consider alcohol addiction as a heterogeneous disorder considering both the etiology and phenotype ${ }^{5,6}$. Differences in phenotype characteristics are reflected in the age at addiction onset, alcohol disease history and history of drinking, comorbid disorders, and occurrence of abstinence difficulties.

When we speak about alcoholism etiology, it is considered that the disease occurs as the consequence of an interaction between the environment and genetic factors ${ }^{7-10}$. Alcohol dependence appears more often among people who have been grown up in an environment tolerant to drinking of alcohol or with a person suffering from a mental disorder ${ }^{11}$. It has also been known for a long time that positive family heredity may be a strong indicator for the occurrence of dependence ${ }^{12}$. In children grown up with a person suffering from alcoholism, the probability of the disease occurrence is threefold that in children whose parents are free from alcoholism. Studies in twins and adopted individuals were conducted to assess the impact of genetic factors. Seven of eight studies of male twins established a significantly higher conformity with monozygotic than with dizygotic twins ${ }^{11}$. Adoptive studies, the best known of which was performed in Stockholm in the $1980 \mathrm{~s}^{13,14}$, speak for the fact that alcohol dependence is a clinically heterogeneous disorder, whereby some forms are more dependent on the inheritance, e.g., the form of alcoholism occurring later in life in a neurotic structure personality (alcoholism type 1) is under a weaker heredity influence (less than $40 \%$ ) as compared with the form of alcoholism where the dependence on alcohol develops earlier in life, followed by antisocial behavior (alcoholism type 2) and where the inheritance influence is very strong (about 90\%). Results of the twins and adoptive studies point to the fact that approximately $50 \%-60 \%$ of the case-studies concerning alcoholism are connected to genetic factors. Taking the paradigm of inheritance into consideration, it is established that alcohol addiction is a very complex polygenetic disease where genetic influence does not reflect in one gene activity effect but in the interactive effect of several ones ${ }^{6,8,13}$.

Mental disorders and behavioral disorders caused by alcohol abuse represent, in regard to stationary hospitalization, the leading psychiatric diagnosis in the Republic of Croatia; $21 \%$ of all patients admitted in 2014 were cases of alcoholism, with a 4.6-6.2:1 male to female ratio ${ }^{15}$. Data on the percentage of patients addicted to alcohol in the general adult population vary depending on the classification or diagnostic criteria applied. Generally, a number of studies report on a $6 \%$ incidence of alcohol addicts in Croatia, whereas in the countries of Western Europe and North America the incidence of alcoholism ranges between $2 \%$ and $12 \%^{16,17}$. As comorbidity of depressive and anxiety disorders, posttraumatic stress disorder and personality disorders is well known and often present in alcohol addicted patients, it is clear that alcohol addiction poses a major public health problem in Croatia, as well as worldwide.

\section{Neurobiological Basis of Alcoholism}

Alcohol is a small molecule, water and lipid soluble, and diffuses easily through cell membranes to be quickly absorbed in blood. Its breakdown occurs in the liver with the help of two enzymes: alcohol dehydrogenase $(\mathrm{ADH})$ oxidizes ethanol into acetaldehyde, which thereafter, with the help of the enzyme aldehyde dehydrogenase (ALDH) transfers into acetate.

Alcohol as a depressor of the nervous system induces sedation, decrease of cognitive and motor functions, etc. Long-term drinking of alcohol brings about 
a series of psychophysical disorders, followed by the loss of neurons in some brain regions (hippocampus, cortex) and finally brain atrophy. The grade of brain atrophy correlates with the quantity of alcohol taken to the body during lifetime ${ }^{18}$. Alcohol intoxication occurs when the alcohol level in the blood reaches the concentration of $50-150 \mathrm{mg} / \mathrm{dL}$, while a concentration of $400-500 \mathrm{mg} / \mathrm{dL}$ is lethal.

The alcohol effect develops through its interaction with various membrane proteins, i.e. enzymes, receptors, neurotransmitting and message system transporters, reflecting on the synaptic transmission ${ }^{19,20}$.

Thanks to numerous researches and studies during the last decades, many of the biochemical, cell and molecular bases of alcohol addiction have become known, revealing that alcoholism as well as other addictions are now to be considered as brain diseases ${ }^{20}$. Various addictive substances also result in changes in various parts of the brain; however, there is a group of brain structures that are affected by all addictive substances, i.e. the so-called brain rewarding system, a part of the limbic system consisting primarily of the tegmentum ventral area (VTA), nucleus accumbens (NAc) and prefrontal cortex (PFC), together with the pathways connecting them, thus forming the medium forebrain bundle (MFB) (Fig. 1). The rewarding system acts by interactions of various neurotransmitters, e.g., dopamine (FDA), serotonin (SHT), noradrenaline (NA), GABAergic (GABA), glutamatergic and other brain systems. We shall, in short, turn to the role of some particular neurotransmitters in alcoholism.

\section{Dopamine}

Dopamine neurons are located in the VTA of the mesencephalon and are grouped into several subgroups (A8, A9 and A10) sending axons to the NAc, $\mathrm{PFC}$, amygdala and the remaining limbic system regions. Precisely, the mesolimbic dopamine has the key role in the alcohol addiction enforcement, as well as in the rewarding, pleasant effect of drinking alcohol ${ }^{21-23}$. The presence of alcohol activates the dopamine A10 neurons in VTA, inducing the release of dopamine in terminal (projection) areas (NAc, PFC and amygdala) and thus increasing dopaminergic neurotransmission. The increased dopamine release is felt as a feeling of satisfaction ${ }^{24}$. Changes arising in the postsynaptic neurons due to long-term excessive neuron DA activity gradually lead to changes in the manner in which the brain reacts to alcohol. Thus, owing to excessive DA availability, the number of dopamine receptors on the postsynaptic membrane decreases and the neuron decreases its dopamine sensitivity, thus allowing for the occurrence of the phenomena such as alcohol tolerance, alcohol craving, abstinence disorders, etc. ${ }^{25,26}$.

\section{Gamma-aminobutyric acid and glutamate}

Gamma-aminobutyric acid (GABA) as the main inhibition neurotransmitter and glutamate as the main excitation neurotransmitter in the brain are also included in the modulation effect of alcohol on the behavior, thus contributing to the development of alcoholism. As distinguished from dopamine with its key role in the rewarding system, these two neurotransmitters also deserve credit for the sedative effects of alcohol, its motor coordination and abstinence symptoms involved in some other aspects of alcoholism.

Drinking alcohol brings inhibition of the glutamate excitation effect with an increase of the GABAergic inhibition. When we speak of long-term alcohol abuse, it leads to self-regulation of transmission, i.e. the glutamatergic transmission effect increases with a simultaneous decrease in GABA effect. This, again, leads to the increased alcohol tolerance. Precisely, this neuroadaptation brings about the abstinence phase difficulties, followed by an increased sensitivity with sweating, anxiety and insomnia ${ }^{27}$. In animal models, it was observed that the GABA-A agonists increased and antagonists decreased the intake of alcohol ${ }^{28}$.

\section{Serotonin}

Serotonergic neurons are found in the raphe cores (raphe nuclei, RN) and are projected in practically every part of the brain. It is considered that they have a significant role in the occurrence of alcohol addiction, primarily due to modulation of other neurotransmitting systems, while numerous studies confirm the role of SHT in all alcohol addiction aspects. We believe today that the lack of serotonergic transmissions leads to increased inclination to alcohol intake $e^{29-31}$ and is also connected to the impulsive and aggressive behavior that is often present in alcohol addicts ${ }^{32,33}$. This especially relates to Cloninger type 2 alcohol addict we shall later speak more about ${ }^{34}$. The decreased SHT 
transmission is also connected to the individual sensitivity to develop alcoholism ${ }^{9,35,36}$, while the possibility that persons who may be carriers of certain gene variants coding the SHT transmitters as the main regulator of the serotonin synaptic transmission, and thus showing greater vulnerability to alcoholism ${ }^{37}$ is an issue of special consideration. The connection between the activities of the serotonin system and alcohol was also shown in animal models, where the level of SHT was modified pharmacologically or surgically and the effects of this manipulation on various alcoholism aspects were observed ${ }^{38,39}$.

\section{Noradrenaline}

Drinking alcoholic beverages motivates the emerging of noradrenergic neurons from the blue core (locus coeruleus) and to excessive activity. Elevated values of NA and its main metabolite 3-methoxy-4hydroxyphenylglycol (MHPG) were found in plasma and cerebrospinal fluid of patients suffering from alcoholism in acute intoxication, as well as when suffering the abstinence crisis ${ }^{26}$. It was also shown that the basal levels of NA and its metabolite were changed in the cortex, hippocampus and limbic system of animals raised by selective breeding according to their inclination to alcohol.

\section{Opioids}

It is considered that opioid peptides participate in the etiology of alcoholism, as shown in clinical and experimental studies on animals. It was observed that the antagonists of opioid receptors (i.e. naltrexone) decrease alcohol intake. Drinking alcohol leads to the release of endogenous opioid peptides (endorphins) which activate the dopamine rewarding system ${ }^{40}$.It is supposed that individual differences in endorphin sensitivity underlay variation of craving for alcohol intensity and therefore represent the risk of developing alcohol addiction ${ }^{41}$.

\section{Neuropeptide $Y$}

Neuropeptide Y (NPY) is richly present in the structures representing the mesolimbic dopamine system (NAc, amygdala), while activation of the NPY receptors is connected with increased food intake and anxiolytic effects. It is considered that through these effects, NPY influences indirectly the intake of alco- hol, and has been investigated as a potential alcohol intake modulator ${ }^{29}$. The mice in which the lack of NPY was induced by a molecular-genetic technique drank significantly more alcohol in the test of a willing choice (two-bottle preference test), whereas the mice with stronger NPY gene expression showed lesser inclination to alcohol and greater sensitivity to its sedation effects ${ }^{42}$.

\section{Subtypes of Alcoholism}

Alcohol addiction is a public health problem and demands constant efforts in finding the mechanisms that lead to inappropriate behavior followed by social and labor dysfunctions ${ }^{43}$. The patients suffering from alcoholism represent a very heterogeneous group from the clinical, etiological and epidemiological points of view. The treatment of alcoholism is very difficult as the disease has frequent relapses, while strategies for its prevention generally prove inefficient.

Alcoholism has been recognized as a disease that is underlain by change in the neurobiological mechanisms as a clear genetic basis, presuming that the diagnosis, if based on the symptomatology, must be heterogeneous as well. It has also been supposed that various medical agents would have variable therapeutic potential in particular patient subpopulations. As the issue of the clinically heterogeneous nature of the addiction was attempted to be solved during the last fifty years, various sub-classifications of patients were suggested. Such a division into subtypes has the purpose to assist in determination of targeted therapy when predicting the disease prognosis ${ }^{35,44,45}$. Clinical studies confirmed that classifying patients into more homogeneous groups would enable setting not only the most effective psychopharmacotherapy but appropriate psychotherapy treatment as well ${ }^{46}$.

The first classification of alcohol addicts was published by Jellinek fifty years ago ${ }^{47}$, who classified patients into 5 subtypes according to the specific clinical qualities (signs of physical dependence, craving, tolerance and loss of control).

Twenty years later, Cloninger et al. performed the first empirical adoptive study resulting in a dichotomy division of alcoholism based on patient characteristics, dividing patients into those with type 1 and those with type 2 alcoholism addiction ${ }^{13}$. 
Type 1 alcohol addictive patients are those whose addiction is manifested later in life (after 25 years of age) and is characterized by a strong influence of external factors (social environment). Both sexes are equally represented and the patients tend to avoid damaging situations and excessive, hard drinking with bouts of abstinence from time to time. About two-thirds of alcohol addicts belong to this type and the disease has a slower course and better prognosis.

Type 2 are those addicts where the addiction emerges earlier in life (before 25 years of age), there is a strong genetic predisposition (family heredity, most often they are children of alcoholic parents). It is considered that type 2 patients are exclusively male patients who tend to antisocial (aggressive) behavior and drink in the first place for 'enjoyment' (and not for 'self-therapy'), they have no wish to avoid the damaging consequences and cannot abstain. They often use other substances of addiction too. Such patients are as a rule more difficult to treat ${ }^{48}$.

According to Cloninger, the alcoholism subtypes also differ according to changes in the brain neurotransmitter systems, proposing that type 1 alcoholism patients have a stronger dopaminergic transmission deficit, while in patients with type 2 alcoholism dopaminergic transmission is not significantly disturbed, but there is a significant defect of the serotonergic transmission ${ }^{34}$. In such a way, he set the so-called neurobiological model of alcoholism. As it connects differences in the neurotransmission with differences in the personality, this model is often called the psychological model of alcoholism.

The Cloninger neurobiological model was significantly confirmed in recent years thanks to the neurochemical, molecular-genetic, pharmacological studies, especially structural (MRI) and functional (PET, SPECT) brain screening ${ }^{49}$. Radiological studies, which tried to connect DA and SHT neurotransmission systems with some particular alcoholic subtypes, showed that type 1 had a decreased DA transmission followed by decreased DA transporter (DAT) density in the striatum, while type 2 showed a lack of 5HT transmitter (5HTT), especially in the front cyngular cortex, dorsal striatum, dorsal amygdala limit and periventricular core of the hypothalamus ${ }^{50,51}$. As in type 1 the $5 \mathrm{HT}$ system changes also exist, but at a much lower extent, it is speculated that these changes are secondary to dopaminergic changes, when compared with the $5 \mathrm{HT}$ system in type 2 already present at an early age $\mathrm{e}^{35}$.

Next to Cloninger classification, there is another dichotomous division in the literature, proposed by Babor et al. ${ }^{52}$ which is, in essence, similar to Cloninger classification, arising from the theory of personality. When compared with Cloninger division, Babor's division is based on the cluster analysis of 321 alcohol addicts, comprising various areas such as personality characteristics, comorbid psychiatric disorders, gravity of alcohol or other psychoactive substance intake, family heredity of alcoholism, as well as the consequences and damages related to drinking. Taken all this into consideration, Babor et al. divide alcohol addicts into type $\mathrm{A}$ and type $\mathrm{B}$, while the basic difference from Cloninger division is in the fact that Babor type $\mathrm{B}$ comprises addicts of both sexes, while Cloninger type 2 consists exclusively of male patients. Such a patient classification has been tested in clinical studies.

A different approach to the classification of alcoholism was suggested by Lesch et al. ${ }^{53,54}$. On the basis of a 5-year study including 444 patients, they suggested division into four categories based on family heredity, psychopathology and hypothetical neurobiological basis. According to Lesch typology, the addicts type 1 (model of allergic reactions) have very strong abstinence difficulties and thus they drink in order to alleviate it. Recent studies point to an increased glutamatergic neurotransmission in this group of patients ${ }^{55}$. Model type II (anxiety or conflict model) are addicts who drink alcohol for its anxiolytic effect with the purpose of self-medication. In addicts type III (depression model), the basic characteristic is the presence of affective disorders. Such patients drink alcohol as an antidepressant. Type IV (adaptation model) includes patients with pre-morbid brain damage, behavior disorder and significant difficulties in social functioning before age 14. A number of studies tried, with more or less success, to associate Lesch alcoholism subtypes with some particular genetic and/or biochemical parameters. For example, an increased peptide level was recorded in type I and type II addicts that showed significant craving for alcohol. Results of a recent study show no connection between Lesch typology and certain polymorphisms in a number of DA and SHT gene systems investigated ${ }^{56}$. 
Apart from these sub-classifications of alcoholism most frequently cited in the literature, there also are others; however, in spite of great efforts invested to define clinical subtypes of alcoholism, which may bring about revision of the diagnostic criteria, none of the suggested classifications has shown any unambiguous results $^{57}$. Therefore, attempts to classify alcoholism subtypes are continued with great patient populations and use of sophisticated statistical methods.

\section{Personalities and Subtypes of Alcoholism}

Current sub-classification of alcoholism is mostly based on patient personalities, their drinking profile and family heredity. In order to establish differences, the researchers rely on psychometric tests/questionnaires to evaluate the individual psychological characteristics. Some of the questionnaires used in the typology of alcoholism research are Tridimensional Personality Questionnaire (TPQ), Treatment and Character Inventory (TCI), Eysenck Personality Questionnaire (EPQ), Minnesota Multiphasic Personality Inventory (MMPI), Connecticut Typology Questionnaire (CTQ), Neuroticism, Extraversion, Openness Personality Inventory (NEO-PI), etc.

Cloninger was the first to embark upon the research of personality connections with biological factors in general and thereafter in alcoholism, specifically suggesting a psychological model of temperament and character where the personality of each individual is represented by 3 basic dimensions of temperament: seeking new excitements (novelty seeking, NS), avoiding damaging behavior (harm avoidance, $\mathrm{HA}$ ), and dependence on reward (reward dependence, $\mathrm{RD})^{48}$. The temperament dimension is a personality component which is hereditary, stable during development, based on emotions, does not depend on social and cultural learning/experience, and is connected to the specific neurobiological characteristics.

Seeking new excitements/events (NS) is defined as compulsive necessity to have new excitements/events and must be undertaken regardless of the physical and social risks they bear. The assumption is that mesolimbic and mesofrontal dopaminergic projections are included in the incentive action of this characteristic and that it is genetically given. Avoidance of harmful behavior (HA, behavior inhibition) is a tendency towards an intensive answer to the aversive motives/ signs bringing about behavioral inhibition connected to the function of the serotonergic system and is thus assumed that the persons with a high HA result on the scale also have an increased release of serotonin from the presynapse and consequently a decreased number of postsynaptic serotonin receptors ${ }^{58}$.

Dependence on reward $(\mathrm{RD})$ is a tendency towards a strong reaction/answer to the reward and repeating the behavior which brought about this reward. It is considered that this dependence is connected to the noradrenergic function as it has been observed that persons with a low result on the RD scale have a decreased release of noradrenaline ${ }^{58}$.

The three given dimensions (NS, HA and RD) represent the basis for Cloninger's Tridimensional Personality Questionnaire (TPQ) and are used in the areas of neurobiology, psychology and psychiatry. Later on, Cloninger suggested an extended model including 4 basic dimensions of temperaments, i.e. NS, HA, RD and persistence, as well as 3 dimensions of the character, i.e. egocentricity (self-directedness), cooperativity (cooperativeness) and altruism (self-transcendence) ${ }^{34}$, making thus the basis of the 7 -factor Temperament and Character Inventory (TCI) model. This model is also used when dividing the normal from the pathological behavior bringing about the occurrence of mental diseases including alcoholism. As distinguished from the temperament dimensions, which are hereditary, it includes the unconscious learning and is connected with various neurotransmitting systems; character dimensions within the mentioned models are connected to the psychology process and represent the function of the temperament, social learning, specific genetic factors and accidental events in life, developing gradually from the childhood till the grown up age. Different measuring scales, if compared, are overlapping to a great extent, i.e. TPQ scale with the NEO-PI scale shows that HA (TPQ scale) corresponds to neuroticism (NEO-PI scale), while seeking for excitement (TPQ scale) corresponds to extrovert characteristic (NEO-PI scale) $)^{59,60}$.

As already mentioned here, some personality characteristics are connected to changes in various neurotransmitting systems. Confirmation of the neurochemical basis of differences between personality characteristics was received from various researches 
including molecular-genetic, neurochemical (receptor bondage, peripheral models, brain screening, etc.) and pharmacological ones ${ }^{35,49}$.

Briefly, pursuant to the hitherto acquired knowledge, it seems that in type 1 alcoholism an expressive characteristic of damage avoidance (HA) is present, as well as a decreased DA transmission and increased SHT transmission, whereas type 2 alcoholism is characterized by seeking excitement (NS), unchanged DA transmission and decreased SHT transmission. These neurochemical differences between the subtypes of alcoholism represent the basis for different therapeutic approach to these patients.

\section{Genetic Basis of Alcohol Addiction}

Results of numerous family studies, twin studies and adoptive studies point to the fact that alcoholism addiction is hereditary in more than $50 \%$ of cases $^{5,7,31}$, and, even more, the alcohol intake model itself is hereditary as well (alcohol quantity, frequency of intoxication, etc. $)^{8,36}$. Thus, exposure to alcohol changes the expression of different genes in the human brain and in experimental animals ${ }^{6,9}$. The model of alcoholism inheritance has not yet been fully clarified, however, it is supposed that the disease is connected to a larger number of genes (polygenetic) included in neurotransmission, cell mechanisms (i.e. intracellular signalization, cell response to stress, etc.) and the general metabolic functions (metabolism of alcohol, lipid metabolism, etc.), with simultaneous influence of the environment and the interaction of the genes and the environment ${ }^{6,10}$.

A strong inheritance component concerning alcoholism speaks for the existence/inheritance of the functional variances of the genes participating in the alcohol metabolism, neurobiology of reward, cognitive functions, etc. ${ }^{?}$.

One of the most frequent forms of the genetic basis of alcoholism are association studies assessing whether a connection exists between a certain genotype or allele in the candidate gene and a specific phenotype (within the family or in relation to the healthy population).

Of the genes included in the neurotransmitting systems, the most researched ones are the genes coding GABA-A and GABA-B receptors, dopamine
D2 receptors, dopamine transporter, serotonin transporter, and serotonin $5 \mathrm{HT}-1 \mathrm{~B},-2 \mathrm{~A}$ and $2 \mathrm{C}$ receptors; however, in all cases, the results of various studies are not consistent ${ }^{10,36}$. One of the reasons for this is surely the great heterogeneity of patients considering their addiction grade, comorbidity, craving, etc. As already mentioned herein, it has been assumed for long now that the contribution of genetic factors is stronger in some types of alcoholism ${ }^{13,14}$.

In the last years, in our research of alcoholism we have come across studies investigating the function of a certain alcoholism subtype with the occurrence of polymorphisms in the genes coding the synaptic proteins included in the development of alcoholism. So, a connection was observed between alcoholism type I and the polymorphic variant (position -602 in region 5) of the NPY gene. It is considered that this gene has a role in the anxiety regulation. Polymorphism in the gene for serotonin transmitter, responsible for its lower activity (s-form 5HTTLPR polymorphism) is connected to alcoholism type 2 but also to the characteristics such as aggressiveness and antisocial behavior $^{5,62}$.

\section{Neuropharmacological Treatment of Alcoholism}

Alcoholism, in addition to the clear psychosocial component, is in its basis a brain disease. The use of pharmacotherapy enforces the psychosocial treatment effects and improves significantly therapeutic effect.

Fundamental and clinical research of alcoholism has shown that several brain transmitter systems have an important role in the etiology of addiction. This has facilitated considerably and directed the development of specific pharmacotherapy. Unfortunately, the pharmacotherapeutic effect of medications is generally speaking rather modest, although it is to a great extent present in various clinical studies. Of the medications we use today we shall mention a few.

Naltrexone is an antagonist of the (mu) and (e kappa) opioid receptor. Its basic pharmacological effect on the intake of alcohol relates to the blockade of the opioid receptors connected with the intake of alcohol, as well as modulation of the neurotransmitters connected to the opioid system. It is used in the addiction treatment of opiates and alcohol in a daily dose of $5 \mathrm{mg}$. Although most studies showed a rather 
poor pharmacotherapeutic effect, persons with certain clinical characteristics such as strong craving for alcohol and family history of alcoholism respond well to naltrexone ${ }^{63}$. Some authors describe greater efficacy of naltrexone in the Babor alcohol addict type $\mathrm{A}$, while others say the same for Cloninger type $2^{64,65}$.

Acamprosate is a glutamate receptor NMDA antagonist assisting in maintenance of abstinence, acting in such a way that the balance between the excitation (glutamate) and inhibition (GABA) neurotransmission is established again after being disturbed by chronic intake of alcohol. Results of clinical studies testing the pharmacotherapy effects of acamprosate are very different. While some authors, especially in Europe, show clear efficacy, the opinions in the USA vary $^{66,67}$. Thus, different effects of acamprosate were shown in various subtypes of alcoholism. For example, the application of acamprosate prolonged the abstinence period in Lesch type I and type II patients, whereas no positive effects were recorded in type III and type IV patients ${ }^{68}$.

Selective inhibitors of the serotonin return intake (selective serotonin reuptake inhibitors, SSRIs) act in such a way that they increase the serotonin presence in the synaptic fissure, thus increasing the serotonergic neurotransmission. Clinical studies in various animal models have consistently demonstrated that SSRI reduced the intake of alcohol; however, the clinical fact is much less clear. The assumption is that the application of functionally different serotonergic agents (SSRI antagonist receptors, etc.) may lead to different effect in different subtypes of alcoholism ${ }^{33}$. Of SSRIs, the pharmacotherapy effect of fluoxetine was studied, as it shows affinity for 5-HT2 receptors and could thus influence the craving and impulsiveness in type $\mathrm{B}$ and type 2 alcoholism. Contrary to expectations, fluoxetine was even less effective in this type of alcoholism, except for cases with comorbid anxiety disorders or mood disorders ${ }^{69}$. Another SSRI, sertraline, was shown to have effect in type $A$ addicts, whereas no effect was observed in type B alcoholism ${ }^{70}$. Accordingly, one may say that SSRI did not show any efficiency if the group of tested patients was heterogeneous but it may be of use in personalized pharmacotherapy.
Ondansetron is a selective antagonist of the 5-HT3 receptor. The brain 5-HT3 receptors are ionic canals alcohol may bind on and they participate in the alcohol effect modulation via interaction with dopamine. The blockade of the 5-HT3 receptor weakens the release of dopamine and, as proven in animals, decreases alcohol intake ${ }^{38}$.

A double blind, placebo controlled study that included 271 alcohol addicts showed that ondansetron decreased the intake of alcohol and prolonged the abstinence period in type $\mathrm{B}$ patients, whereas no positive ondansetron effect was observed in type $A$ patients ${ }^{45,69}$.

Disulfiram is a drug which, unlike those described above, does not act on neurotransmission, has been in use since 1940, and most probably still is the most frequently used drug in alcoholism therapy, both in the world and in our clinical practice. The mechanism of disulfiram effect is metabolic ALDH inhibition causing the accumulation of acetaldehyde in blood and, consequently, leading to unpleasant effects (sweating, headache, vomiting and similar) if the intake of alcohol is continued. Disulfiram has no effect on craving for alcohol and the patient must be very motivated to take disulfiram on his/her own free will.

When choosing therapy, an important aspect is the previously mentioned fact that some persons do have predisposition against alcohol. It is to be expected that such persons will benefit from a precisely specific therapy directed toward the disorders underlain by their vulnerability against alcoholism. This would be important when we speak of recognizing the individuals, children and/or adults who are more vulnerable when we speak of alcohol, when variations in some neurobiological areas should be taken in consideration. This is also the reason why the gene candidates are studied and why personality studies are being conducted.

The clinical purpose of establishing the alcoholism subtypes is precisely to set the process in behavioral and pharmacological therapy which may best help a particular individual. Therapy individualization is especially important when we speak of serotonergic medications, where the SSRIs are more effective in type I/A patients and antagonists of $5 \mathrm{HT} 3$ receptors in type $2 / \mathrm{B}$ alcoholism. 


\section{Monoamine Oxidase (MAO)}

\section{Classification, distribution and role of $M A O$}

The enzyme monoamine oxidase (MAO, E.C1. 4.3.4.) is an integral protein of the external mitochondrion membrane acting as a catalyst for oxidative deamination in the brain and peripheral tissue, controlling in such a way their concentration. It occurs in two forms, MAO-A and MAO-B, which differ according to molecular mass, affinity for substrates and sensitivity of its inhibitors.

The isoenzyme A acts as a catalyst for the breakdown of the larger endogenous amine neurotransmitters such as serotonin, noradrenaline and adrenaline, and shows higher sensitivity for the irreversible inhibitor clorgiline, whereas the isoenzyme B breaks down primarily small endogenous and exogenous amines such as benzylamine and beta-phenylethylamine because it is sensitive to the irreversible inhibitors pargyline and deprenyl. Both MAO types have an equal affinity towards dopamine amine and tryptamine. Specific quality of isoenzyme against the substrate is determined with the aliphatic and aromatic side branches of amino acids at an active site. Depending on the substrate concentration, both isoenzymes may metabolize all the mentioned substrates. The presence of $\mathrm{MAO}$ was proven in almost all tissues, whereby the MAO-A and MAO-B differ according to their distribution in tissues and localization in the cells. The highest concentration of both isoenzymes is found in the liver, while greater MAO levels are present in the spleen, small intestine, lungs, kidneys and adrenal gland. $\mathrm{Hu}-$ man placenta also has high MAO-A contents, while $\mathrm{MAO}-\mathrm{B}$ form is found mostly in platelets and lymphocytes $^{70}$. A high level of MAO is found in human brain, as shown by catecholaminergic neurons (noradrenergic, adrenergic and dopaminergic), especially in the NA-core locus coeruleus, while MAO-B is mostly present in serotonergic neurons (especially in the raphe cores), histaminergic neurons, glial cells and ependymal cells. The MAO-A distribution in brain reflects the distribution of the natural enzyme substrates, while the possible role of MAO-B serotonergic neurons is to prevent the accumulation of various substrates that may interfere with $5-\mathrm{HT}$ metabolism.

\section{Isoenzyme $M A O-A$ and $M A O-B$ structure}

The amino acid sequence of the MAO-A and $\mathrm{MAO}-\mathrm{B}$ in humans has been known for some 20 years ${ }^{71}$. Isoenzymes A and B are composed of 527 and 520 amino acids, their molecular mass is 59700 and 58000 , respectively, and they show $70 \%$ of identical amino acid sequences. Both sequences contain pentapeptide Ser-Gly-Gly-Cy-Tyr covalently connected to the coenzyme flavin adenine dinucleotide $(\mathrm{FAD})^{72}$.

The primary structure of both MAO isoenzymes consists of three regions, i.e. a region in the amino end vicinity, so-called Rossmann fold, an area that non-covalently binds FAD; a region responsible for the specific quality (located in the middle of the enzymes); and the area binding FAD. Besides these regions, at the very carboxy-end of the enzyme is an essentially hydrophobic region the role of which would be to ensure fixing of proteins in the external membrane of the mitochondrion or it may represent the signal for its direction. Difference in the catalyst activity of MAO-A and MAO-B is the consequence of difference in their amino acid sequences ${ }^{70}$.

\section{$M A O-A$ and $M A O-B$ gene structure}

Isoenzymes $\mathrm{MAO}-\mathrm{A}$ and $\mathrm{MAO}-\mathrm{B}$ originate from two separate genes located on the shorter $\mathrm{X}$ chromosome branch in the region $\mathrm{X}_{\mathrm{p}}$ 11.23-11.4. The length of both genes amounts to 60 to $70 \mathrm{~kb}$, both are composed of an equal number of exons $(n=15)$ and both have the same exon and intron organization, suggesting that they have emerged by duplication of the same progenitor gene. Both $\mathrm{MAO}$ amino acid sequences in humans and rats show $88 \%$ conformity ${ }^{72}$.

Significant differences between MAO-A and $\mathrm{MAO}-\mathrm{B}$ genes exist in transcription elements in promoter organizations and precisely these differences are responsible for various tissue and cell expression of individual enzyme, especially when bound to the catecholaminergic and serotonergic brain neurons ${ }^{70,73}$.

In the past twenty years, owing to development of the molecular-genetic technique, a large number of polymorphic sites in the genes for MAO-A and $\mathrm{MAO}-\mathrm{B}$ have been detected. The gene represents a sequence of nucleotides placed in a special position on the chromosome (locus). The genes located on the 
same loci on homologous chromosomes are called alleles and they supervise always the same phenotype characteristic. One pair of alleles on a certain locus represents an individual genotype and these alleles can also be identical (the individual is a homozygote for a certain characteristic) or they may differ (a heterozygote for this characteristic). There are natural variations in all genes and if one variation appears in at least $1 \%$ of the population it is called polymorphism. The most frequent polymorphism forms we encounter are substitutions of one nucleotide basis (single nucleotide polymorphism, SNP), double sequence of a certain number of base pairs, and insertion/deletion of DNA segment from certain base pair numbers.

The following polymorphic gene locations for $\mathrm{MAO}-\mathrm{A}$ are described in the literature: variable number of tandem repeats (VNTR) polymorphism in the promotor gene consisting of a various number of repeats $(3,3.5,4,5)$ of the sequence of 30 base pairs whose presence influences the transcription activity/ functionality; VNTR in intron 1; a highly polymorphic microsatellite repeating sequence $(\mathrm{CA}) \mathrm{n}$ in intron 2; several point mutations ( $\mathrm{SNPs}$ ) in the coded region bringing the synthesis of imperfect protein, and others. In the gene for MAO-B, three polymorphic locations have been detected: $\mathrm{C}-1,114 \mathrm{~T}$ polymorphism in promoted $(\mathrm{GT}) \mathrm{n}$ repeated sequence $(\mathrm{n}=18-29)$ in intron 2, and $\mathrm{A} / \mathrm{G}$ dimorphism in intron 13.

The presence of a certain polymorphism within a gene or a combination of several polymorphisms on one or different genes may contribute to inter-individual differences in the personality of an individual and vulnerability to a certain disease including alcoholism, as well as differences in pharmacotherapeutic response. MAO is the best investigated VNTR polymorphism in the gene promoter for MAO-A whose presence has greatest influence when we speak of the transcription activity/functionality.

\section{$M A O$ and the platelet model}

Platelets are small nuclear blood cells participating in keeping the blood vessel system integrity and possess a few serotonin elements showing biochemical and pharmacological similarities with the analog elements in the serotonergic neurons. This similarity of the platelets with neurons, as well as easy accessibility of the platelets in vivo makes them an appropriate peripheral model for serotonergic mechanism research in neurobiology and biologic psychiatry.

The human platelet serotonin system includes dense granules with stored serotonin, serotonin transporter (5HTT) and serotonin 2A (5HT-2A) receptor on the platelet membrane, and the mitochondrial enzyme MAO. All three platelet proteins are bound to the serotonin system 5HT, 5HT-A receptor and $\mathrm{MAO}$ and are, structurally, equal to the brain ones, coded with the same genes, a fact also speaking for the use of platelets as a model in neurobiology. One should, however, mention the fact that there are rather contradictory opinions regarding the value of platelet model; namely, it has been demonstrated that there is no correlation between the brain and platelet MAO-B activity, thus pointing to their different regulation. Unlike this, however, central $\mathrm{MAO}$ and platelet MAO values show very good correlation after pharmacological inhibition.

The platelet MAO activity follows the MichaelisMenten enzyme kinetics. Kinetic parameters Vmax (enzyme catalyst reaction speed measure) and $\mathrm{Km}$ (enzyme affinity towards substrate indicator) depend on the substrate and are calculated from the enzyme saturation curve resulting from measuring the reaction speed catalyzed with enzyme within a certain time period with various substrate quantities and a constant enzyme quantity in the incubation mixture. Healthy humans have a very wide platelet MAO activity span and these values vary to up to 50 times $^{74}$. It is considered that this may be the consequence of endogenous factors (age, sex, genetic variations, hormonal status, circadian rhythm), as well as of exogenous factors such as medication, diet and various pathologic conditions of the body. It has also been observed that female individuals have higher enzyme values, while $\mathrm{MAO}-\mathrm{B}$ activity increases with aging. It is also considered that platelet MAO-B activity is stable over time and genetically stipulated.

Although currently there are differences in the opinions with regard to the platelet model value, the possibility of its use in neurobiology and biologic psychiatry is still under research owing to the benefits we experience from the peripheral indicator of the brain activity. 


\section{Psychological role of $M A O$ and clinical implications}

The primary role of MAO in the brain is oxidative deamination of the neurotransmitting amine catalysis, i.e. serotonin, adrenaline, noradrenaline and dopamine; thus, this enzyme is the key factor in maintaining cytoplasmic concentrations of various neurotransmitters and regulation of the neurotransmitting synaptic activity. MAO also acts as an amine 'cleaner' as such amines are usually found in low concentrations (tyramine, phenylethylamine) and participates in the breakdown of the exogenous inert amines and their derivatives. It is also considered to prevent accumulation of natural substrates (i.e. dopamine) which may interfere with serotonin metabolism ${ }^{75}$.

In peripheral tissues such as the liver, intestines or lung, MAO has a protective function as it oxidizes the amines from the blood or prevents their entering the circulation $^{70,75}$. MAO activity differs according to sex, and concentrations of MAO-A and MAO-B in the brain change in a different way during life. MAO-A appears ontogenetically earlier and at the moment of birth its level equals those throughout life with the exception of a temporary rise in the early postnatal time period. As opposed to this, the MAO-B concentration in the brain increases several times after birth, probably owing to strong astrocyte proliferation, and then it remains relatively stable until the 60ies, when it starts rising again, probably due to proliferation of glial cells as a substitute for declining neurons ${ }^{75}$.

Taken its function into consideration, MAO is the enzyme included in the etiology and pathogenesis of various neuropsychiatric and neurological diseases. Numerous experimental and clinical studies point to the role of MAO in depressive and anxiety disorders, neurologic diseases, Parkinson's disease, Alzheimer's disease), addictive diseases, etc. Selective MAO inhibitors are primarily used in the treatment of depression and have their indication area also in anxiety disorders, panic condition, social phobias, panic situations, bulimia and migraine, whereas selective MAO-B inhibitors are used in neurology for Parkinson's and Alzheimer's disease therapy ${ }^{76}$.

The assumption that a lowered MAO may be an indicator of vulnerability to certain psychiatric diseases is more than 30 years old and, as opposed to the brain, platelets are easily accessible. Many clini- cal studies used platelets as a peripheral model in this enzyme research.

\section{Monoamine Oxidase and Alcoholism Subtypes}

\section{Platelet MAO-B and alcohol addiction}

The finding of decreased platelet MAO-B activity in various psychiatric diseases and disorders has brought about the assumption than this enzyme may be a genetic indicator (trait marker) or a disease condition indicator (state marker) in biologic psychiatry.

However, most recent results point to the fact that the lowered enzyme activity is not directly connected to the disease phenomenon concerning a number of diseases but is connected to various personality characteristics which, again, represent a risk factor in the emergence of various diseases and disorders ${ }^{77,78}$.

Since the mid-1970s, a large number of researches, although not all of them, point to the fact that a decreased platelet MAO-B activity was observed in individuals addicted to alcohol, in particular those diagnosed with the sub-categorized type 2 alcoholism ${ }^{79,80}$. The lowered platelet MAO-B activity was found to be associated with certain characteristic traits such as impulsiveness, lack of adaptation, avoidance of monotony and seeking for excitement ${ }^{81}$. It is also connected to positive characteristics such as creativity, boldness, leadership and management ability ${ }^{82}$. However, it should also be noted that some of the studies did not establish any connection between lowered MAO-B activity and alcohol addiction, whereas some authors did observe transitory increase in the early phase of alcohol abstinence ${ }^{83,84}$.

Also, some thirty years ago, a direct inhibitory effect of cigarettes on platelet MAO-B activity was observed but the smoker status of the study individuals was rarely taken in consideration until recently. The finding, however, reached by the positron emission tomography (PET) technique speaking for a significantly decreased MAO-B activity in the brain and all peripheral tissues made many research results in alcohol addicts also known as heavy smokers questionable.

In recent years, several authors investigated the association of MAO-B, smoking and alcohol but even then the results were not unambiguous. While some studies taking smoking habit of the study indi- 
viduals in consideration report no changes of MAO activity in alcoholic patients, others report on such differences ${ }^{85,86}$. One of many explanations is that study populations were not homogeneous, as the authors in most cases did not divide patients into alcoholic subtypes.

As in the cases of the MAO-B platelet association with psychiatric diseases and disorders, one should also revise the results of its connection with psychological parameters/personality characteristics since these studies did not take the study population smoking habit into consideration either. The research where the authors controlled smoking and other factors in order to find out whether it may affect the MAO activity speaks for the fact that the enzyme connection with some of the personality dimensions actually does exist ${ }^{87}$.

\section{Polymorphic gene variant for $M A O-B$ and alcohol addiction}

One of the polymorphisms in the gene coding MAO-B is the A/G dimorphism (A644G) in intron 13. This polymorphism is actually a point mutation, where one base is exchanged by another ( $A$ or $G$ ) and is located on 36 bases upstream from the intron 13 and exon 14 border. The existence of this polymorphism will not lead to change in the amino acid sequence in the protein but is still involved in the gene transcription regulation and the quantity of enzyme molecules. The in vitro studies show that intron 13 has a very strong inscription activity, higher with the G- than A-alleles ${ }^{88}$. Some authors observed that the platelet $\mathrm{MAO}-\mathrm{B}$ activity is also higher in healthy male individuals carrying $\mathrm{G}$ allele in comparison to those with A-allele. We assume that this polymorphism is inherited together with another one influencing thus the protein structure or any other transcription regulation and the synthesized protein ${ }^{89}$. As opposed to these findings, other authors did not show any association between the enzyme activity and the genotype ${ }^{90}$. The results point to different tissue-specific control mechanisms of the MAO-B activity in the platelets and in the brain.

The MAO-B A/G dimorphism has been mostly researched in Parkinson's disease, where the connection between the A allele and early disease development was demonstrated, yet again, not in all studies ${ }^{91}$.
A combination of genotypes within the genes for $\mathrm{MAO}-\mathrm{B}$ and for dopamine D2 receptor is connected with smoking in humans ${ }^{92}$. The connection of the $A / G$ dimorphism with some personality characteristics has hitherto not been observed ${ }^{93}$. We also presume that the connection between this genetic variance and a particular phenotype is sex dependent ${ }^{94}$, a fact also considered important in pharmacotherapy.

Considering the association with alcohol addiction, there are several studies researching the connection of polymorphisms in the genes coding $\mathrm{MAO}$ and alcoholism, but they refer primarily to the VNTR polymorphism in the regulator gene region for MAO-A, where it is considered to influence the enzyme activity/functionality transcription. It seems that an allele with 3 repeats and a lower transcription activity represents the risk allele for vulnerability to alcoholism, primarily with regard to the antisocial form and antisocial behavior type when under alcohol intoxication in general and in connection of the genotype and the phenotype has been modulated with psychosocial conditions; a significantly stronger connection was recorded in the individuals that had been abused sexually or in childhood ${ }^{95,96}$. Some studies also took the type of alcoholism in consideration, but difference between these types was either not shown at all or only a higher presence of 3-repeat allele was recorded in type 2 alcoholism $^{97,98}$. According to some results, it seems that MAO-A genotype is a better prognostic indicator for smoking intensity in the individuals addicted to alcohol who are very heavy smokers ${ }^{99}$.

Although the MAO-B activity is genetically stipulated, so that even $70 \%$ of its variable activity may be explained by inheritance, the research related to the MAO-B genotype and different psychiatric diseases, as well as the personalities connected to a certain disease are much less represented and there are almost none in alcoholism. Our preliminary studies performed in a small number of individuals did not show differences in the MAO-B genotype between the patients suffering from alcoholism and control population ${ }^{100}$. A study in a small number of female patients addicted to alcohol revealed that, as opposed to MAO-A, the MAO-B haplotype was connected to alcoholism independently of the antisocial behavior ${ }^{95}$. 


\section{References}

1. American Psychiatric Association. Diagnostic and Statistical Manual of Mental Disorders, $4^{\text {th }}$ ed. Washington: American Association Press; 1994. p. 866.

2. World Health Organization. Manual of the International Statistics of Disease, Injuries and Causes of Death. $10^{\text {th }}$ revision, Geneva: World Health Organization; 1992.

3. Morse RM, Flavin DK. The definition of alcoholism. The Joint Committee of National Council on Alcoholism and Drug Dependence and the American Society of Addiction Medicine to Study the Definition and Criteria for the Diagnosis of Alcoholism. JAMA. 1992;268(8):1012-4.

4. American Psychological Association. Dictionary of Psychology, $1^{\text {st }}$ ed. Washington: Gary R Vanden Bos; 2007. p. 233.

5. Kohnke MD. Approach to the genetics of alcoholism: a review based on pathophysiology. Biochem Pharmacol. 2008;75(1):160-77.

6. Rodd ZA, Bertsch BA, Strother WN, Le-Niculescu H, Balaraman J, Hayden E, et al. Candidate genes, pathways and mechanisms for alcoholism: an expanded convergent functional genomics approach. Pharmacogenomics. 2007;7(4):222-56.

7. Oroszi G, Goldman D. Alcoholism: genes and mechanisms. Pharmacogenomics. 2004;5(8):1037-48.

8. Hiroi N, Agatsuma S. Genetic susceptibility to substance dependence. Mol Psychiatry. 2005;10(4):336-44.

9. Lesch KP. Alcohol dependence and gene X environment interaction in emotion regulation: is serotonin the link? Eur J Pharmacol. 2005;526 (1-3):113-24.

10. Goldman D, Oroszi G, Ducci F. The genetics of addictions: uncovering the genes. Nat Rev Genet. 2005;6(7):521-32.

11. McGue M. Behavioral genetic models of alcoholism and drinking. In: Leonard KE, Blane HT, editors. Psychological theories of drinking and alcoholism. New York: Guilford Press; 1999. p. 372-420.

12. Cotton NS. The familial incidence of alcoholism: a review. J Stud Alcohol. 1979;40(1):89-116.

13. Cloninger CR, Bohman M, Sigvardson S. Inheritence of alcohol abuse. Cross-fostering analysis of adopted men. Arch Gen Psychiatry. 1981;38(8):861-8.

14. Cloninger CR. Neurogenetic adaptive mechanisms in alcoholism. Science. 1987;236(4800):410-6.

15. Hrabak-Žerjavić V, Silobrčić-Radić M. Epidemiološki prikaz duševnih bolesti i poremećaja. Hrvatski časopis za javno zdravstvo. [Internet] 2006 Oct [cited 2015 June 18]; 8(2): [about 5p.] Available from: http://www.izlog.info/tmp/hcjz/ arhiva.php (in Croatian)

16. Thaller $\mathrm{V}$, et al. Alkohol kao psihoaktivna tvar. In: Thaller V, et al., editors. Alkohologija. $1^{\text {st }}$ ed. Zagreb: Naklada CSCAA; 2002. p. 32-49. (in Croatian)

17. Thaller V, et al. Epidemiologija. In: Thaller V, et al. Alkohologija. $2^{\text {nd }}$ ed. Zagreb: Naklada CSCAA; 2002. p. 3-16. (in Croatian)
18. Harper C, Matsumoto I. Ethanol and brain damage. Curr Opin Pharmacol. 2005;5(1):73-8.

19. Fadda F, Rossetti ZL. Chronic ethanol consumption: from neuroadaptation to neurodegeneration. Prog Neurobiol. 1998;56(4):385-431.

20. Ross S, Peselow E. The neurobiology of addictive disorders. Clin Neuropharmacol. 2009;32(5):269-76.

21. McBride WJ, Murphy JM, Gatto Gj, Levy AD, Lumeng L, Li TK. Serotonin and dopamine systems regulating alcohol intake. Alcohol Alcohol.1991;26 (Suppl 1):411-6.

22. Tupala E, Tiihonen J. Dopamine and alcoholism: neurobiological basis of ethanol abuse. Prog Neuropsychopharmacol Biol Psychiatry. 2004;28(8):1221-47.

23. Nestler EJ, Hope T, Widnell KL. Drug addiction, a model for the molecular basis of neural plasticity. Neuron. 1993;11(6):995-1006.

24. Kiefer F, Mann K. New achievements and pharmacotherapeutic approaches in the treatment of alcohol dependence. Eur J Pharmacol. 2005;526(1-3):163-71.

25. Wise RA. The neurobiology of craving: implications for the understanding and treatment of addiction. J Abnormal Psychol. 1988;97(2):118-32.

26. Heinz A, Schmidt K, Baum SS, Kuhn S, Dufeu O, Schmidt LG. Influence of dopaminergic transmission on severity of withdrawal syndrome in alcoholism. J Stud Alcohol. 1996;57(5):471-4.

27. Grobin AC, Mathews DB, Devaud LL, Morow AL. The role of GABA receptors in the acute and chronic effects of ethanol. Psychopharmacology. 1988;139(1-2):2-19.

28. Boyle AE, Segal R, Smith BR, Amit Z. Bidirectional effects of GABAergic agonist and antagonists on maintenance of voluntary ethanol intake in rats. Pharmacol Biochem Behav. 1993;46(1):79-182.

29. Goodman A. Neurobiology of addiction. An integrative review. Biochem Pharmacol. 2008;75(1):266-322.

30. Holmes A, Spanagei R, Krystal JH. Glutamergic targets for a new alcohol medications. Pscychoparmacology. 2013;229(3):539-54, doi: 10.1007/s00213-013-3226-2

31. Worst TJ, Vrana K. Alcohol and gene expression in the central nervous system. Alcohol Alcohol. 2005;40(1):63-75.

32. Mosner A, Kuhlman G, Roehm C. Serotonergic receptors modify the voluntary intake of alcohol and morphine but not of cocaine and nicotine by rats. Pharmacology. 1997;54(4):186-92.

33. Johnson BA. Serotonergic agents and alcoholism treatment: rebirth of the subtype concept - a hypothesis. Alcohol Clin Exp Res. 2000;24(10):1597-601.

34. Cloninger CR. The psychobiological regulation of social cooperation. Nat Med. 1995;1(7):623-5.

35. Leggio L, Addolorato G. Serotonin transporter (SERT) brain density and neurobiological Cloninger subtypes model: 
a lesson by human autoradiography studies. Alcohol Alcohol. 2008;43:148-50.

36. Dick DM, Foroud T. Candidate genes for alcohol dependence: a review of genetic evidence from human studies. A1cohol Clin Exp Res. 2003;27(5):868-79.

37. Feinn R, Nellissery M, Kranzler HR. Meta-analysis of the association of a functional serotonin transporter promoter polymorphism with alcohol dependence. Am J Med Genet B Neuropsychiatr Genet. 2005;133(1):79-84.

38. McBride WJ, Li TK. Animal models of alcoholism: neurobiology of high alcohol-drinking behaviour in rodents. Crit Rev Neurobiol. 1998;12(4):339-69.

39. Kiianmaa K, Stenius K, Sinclair JD. Determinants of alcohol preference in the AA and ANA rat lines selected for differential ethanol intake. Alcohol Alcohol. 1991;26 (Suppl 1):115-20.

40. Benjamin D, Grant E, Pohorecky LA. Naltrexone reverses ethanol-induced dopamine release in the nucleus accumbens in awake, freely moving rats. Brain Res. 1993;621(1):137-40.

41. Gianoulakis C. Implications of endogenous opioids and dopamine in alcoholism: human and basic science studies. Alcohol Alcohol. 1996;31(1):33-42.

42. Thiele TE, Marsh DJ, Ste-Marie L, Bernstein IL, Palmiter RD. Ethanol consumption and resistance are inversely related to neuropeptide Y levels. Nature. 1988;396:366-9.

43. Potkonjak J, Ivančić I, Zdunić D, Karlović D, Matošić A. A1coholic and his family. Alcoholism. 2006;42:23-33.

44. Addolorato G, Abenavoli L, Leggio L, Gasbarini G. How many cravings? Pharmacological aspects of craving treatment in alcohol addiction: a review. Neuropsychobiology. 2005;51(2):59-66.

45. Roache JD, Wang Y, Ait-Daoud N, Johnson BA. Prediction of serotonergic treatment efficacy using age of onset and type a/b typologies of alcoholism. Alcohol Clin Exp Res. 2008;32(8):1502-12. doi: 10.1111/j.1530-0277 .2008.00717.x.

46. Litt MD, Babor TF, DelBoca FK, Kadden RM, Cooney NL. Types of alcoholics II. Application of an empirically derived typology to treatment matching. Arch Gen Psychiatry. 1992;49(8):609-14.

47. Jellinek EM. The Disease Concept of Alcoholism. New Brunswick: Hillhouse Press; 1960.

48. Cloninger CR. A systematic method for clinical description and classification of personality variants. A proposal. Arch Gen Psychiatry. 1987;44(6):573-88.

49. Gardini S, Cloninger CR, Venneri A. Individual differences in personality traits reflect structural variance in specific brain regions. Brain Res Bull. 2009;79(5):265-70. doi: 10.1016/j. brainresbull.2009.03.005.

50. Mantere T, Tupala E, Hall H, Sarkioja T, Rasanen P, Bergstrom K. Serotonin transporter distribution and density in the cerebral cortex of alcoholic and nonalcoholic comparison subjects: a whole-hemisphere autoradiography study. Am J Psychiatry. 2002;159(4):599-606.

51. Storvik M, Haukijarvi T, Tiihonen J, Tupala E. Amygdala serotonin transporters in alcoholics measured by whole hemisphere autoradiography. Synapse. 2007;61(8):629-36.

52. Babor TF, Hofman MI, DelBoca FK, Hesselbrock V, Meyer RE, Dolinsky ZS. Types of alcoholics I. Evidence for an empirically derived typology based on indicator of vulnerability and severity. Arch Gen Psychiatry. 1992;49(8):599-608.

53. Lesch OM, Kefer J, Lentner S, Mader R, Marx B, Musalek $\mathrm{M}$. The course of alcoholism. Long-term prognosis in different subtypes. Forensic Sci Int. 1988;36:121-36.

54. Lesch OM, Walter H. Subtypes of alcoholism and their role in therapy. Alcohol Alcohol. 1996;31(1):63-7.

55. Hillemacher T, Bayerlein K, Wilhelm J, Bonsch D, Poleo D, Sperling W, Kornhuber J, Bleich S. Recurrent detoxifications are associated with craving in patients classified as type 1 according to Lesch typology. Alcohol Alcohol. 2006;41(1):66-9.

56. Samochowiec J, Kucharska-Mazur J, Grzywacz A, Pelka Wysiecka J, Mak M, Samochowiec A. Genetics of Lesch typology of alcoholism. Prog Neuropsychopharmacol Biol Psychiatry. 2008;32(2):423-7.

57. Babor TF, Caetano R. Subtypes of substance dependence and abuse: implication for diagnostic classification and empirical research. Addiction. 2006;(Suppl. 1):104-10.

58. Gerra G, Zaimović A, Timpano M, Zambelli U, Delsignore R, Brambilla F. Neuroendocrine correlates of temperamental traits in humans. Psychoneuroendocrinology. 2000;25(5):479-96.

59. Costa PT, McCrae RR. Personality disorders and the fivefactor model of personality. J Pers Disord. 1990;4:362-71.

60. Higuchi S, Matsushita S, Kashima H. New findings on the genetic influences on alcohol use and dependence. Curr Opin Psychiatry. 2006;19(3):253-65.

61. Mottagui-Tabar S, Prince JA, Wahlestedt C, Zhou G, Goldman D, Heillig M. A novel single nucleotide polymorphism of neuropeptide Y (NPY) gene associated with alcohol dependence. Alcohol Clin Exp Res. 2005;29(5):702-7.

62. Johnson BA. Update on neuropharmacological treatment for alcoholism: scientific basis and clinical findings. Biochem Pharmacol. 2008;75(1):34-56.

63. Bogenschultz MP, Scott Tonigan J, Pettinati HM. Effects of alcoholism typology on response to naltrexone in the COMBINE study. Alcohol Clin Exp Res. 2008;305:1530-43. doi: 10.1111/j.1530-0277.2008.00804.x

64. Kiefer F, Jimenez-Arriero MA, Klein O, Diehl A, Rubio G. Cloninger's typology and treatment outcome in alcohol dependent subjects during pharmacotherapy with naltrexone. Addict Biol. 2008;13(1):124-9.

65. Mason BJ, Crean R. Acamprosate in the treatment of alcohol dependence: clinical and economic considerations. Exp Rev Neurother. 2008;7(11):1465-77. 
66. Anton RF, Malley SS, Ciraulo DA, Cisler RA, Couper D, Donovan DM. Combined pharmacotherapies and behavioral interventions for alcohol dependence. The COMBINE study: a randomized controlled trial. JAMA. 2006;295:2003-17.

67. Lesch OM, Riegler A, Gutierrez K, Hertling I, Ramskogler $\mathrm{K}$, Semler B. The European acamprosate trials: conclusions for research and therapy. J Biomed Sci. 2001;8(1):89-95.

68. Kranzler HR, Pieruci-Lagha A, Feinn R, Hernandez-Avila C. Effects of ondansetron in early- versus late-onset alcoholics: a prospective open-label study. Alcohol Clin Exp Res. 2003;27(7):1150-5.

69. Pettinati HM, Volpicelli JR, Kranzler HR, Luck G, Rukstalis MR, Cnaan A. Sertraline treatment for alcohol dependence: interactive effects of medication and alcohol subtype. Alcohol Clin Exp Res. 2000;24(7):1041-9.

70. Nagatsu Z. Progress in monoamine oxidase (MAO) research in relation to genetic engineering. Neurotoxicology. 2004;25(1-2):11-20.

71. Bach AWJ, Lan NC, Johnson DL, Abell CW, Bembenek ME, Kwan SW, Seeburg PH, Shih JC. cDNA cloning of human liver monoamine oxidase A and B: molecular basis of differences in enzymatic properties. Proc Natl Acad Sci USA. 1988;85(13):4934-8.

72. Shih JC. Monoamine oxidase: from tissue homogenates to transgenic mice. Neurochem Res. 2007;32(10):1757-61.

73. Shih JC, Chen K. Regulation of MAO-A and MAO-B expression. Curr Med Chem. 2004;11(15):1995-2005.

74. Veral A, Alper G, Menter G, Ersoz B. Age and sex related alterations in serum and platelet monoamine oxidase. Eur J Clin Chem Clin Biochem. 1997;35(4):265-8.

75. Youdim MBH, Edmondson D, Tipton KF. The therapeutic potential of monoamine oxidase inhibitors. Nat Rev Neurosci. 2006;7(4):295-309.

76. Bortolato M, Chen K, Shih JC. Monoamine oxidase inactivation: from pathophysiology to therapeutics. Adv Drug Deliv Rev. 2008;60(13-14):1527-33. doi: 10.1016/j. addr.2008.06.002

77. Ruchkin VV, Koposov RA, af Klinteberg B, Oreland L, Grigorenko EL. Platelet MAO-B, personality and psychopathology. J Abnorm Psychol. 2005;114(3):477-82.

78. Oreland L, Hallman J, Damberg M. Platelet MAO and personality - function and dysfunction. Curr Med Chem. 2004;11(15):2007-16.

79. Cloninger CR, Sigvardson S, Bohman M. Type I and II alcoholism: an update. Alcohol Health Res World. 1996;20:1823.

80. Oreland L. Platelet monoamine oxidase, personality and alcoholism: the rise, fall and resurrection. Neurotoxicology. 2004;25(1-2):79-89.

81. Hallman J, von Knorring L, Oreland L. Personality disorders according to DSM III-R and thrombocyte monoamine oxidase activity in type 1 and type 2 alcoholics. J Stud Alcohol. 1996;57(2):155-61.
82. Damberg M, Garpenstrand H, Hallman J, Oreland L. Genetics mechanisms of behaviour - don't forget about the transcription factors. Mol Psychiatry. 2001;6(5):503-10.

83. Soyka M, Bondy B, Benda E, Preuss U, Hegerl U, Moller HJ. Platelet monoamine oxidase activity in alcoholics with and without a family history of alcoholism. Eur Addict Res. 2000;6(2):57-63.

84. Berggren U, Fahlke C, Balldin J. Transient increase in platelet monoamine oxidase B activity during early abstinence in alcoholics: implications for research. Alcohol Alcohol. 2000;35:377-80.

85. Cicin-Sain L, Matosic A, Mokrovic G, Balija M, Marusic $\mathrm{S}$, Jernej B. Platelet monoamine oxidase kinetics, alcoholism subtypes and cigarette smoking. Neuropsychobiology. 2008;56(2-3):138-45, doi: 10.1159/000115780

86. Eensoo D, Paaver M, Pulver A, Harro M, Harro J. Low platelet MAO activity associated with high dysfunctional impulsivity and antisocial behavior: evidence from drunk drivers. Psychopharmacology. 2004;172(3):356-8.

87. Pombo S, Levy P, Bicho M, Ismail F, Neves Cardoso JJM. Neuropsychological function and platelet monoamine oxidase activity levels in type I alcoholic patients. Alcohol Alcohol. 2008;43:423-30.

88. Costa-Mallen P, Kelada SN, Costa LG, Checkoway H. Characterization of the in vitro transcriptional activity of polymorphic alleles of the human monoamine oxidase-B gene. Neurosci Lett. 2005;383(1-2):171-5.

89. Garpenstrand H, Ekblom J, Forslund K, Rylander G, Oreland L. Platelet monoamine oxidase activity is related to MAOB intron 13 genotype. J Neural Transm. 2000;107(5):523-30.

90. Filic V, Vladic A, Stefulj J, Cicin-Sain L, Balija M, Sucic Z, Jernej B. Monoamine oxidases A and B gene polymorphysms in migraine patients. J Neurol Sci. 2005;228(2):149-53.

91. Parsian A, Racette B, Zhang ZH, Rundle M, Perlmutter JS. Association of variation in monoamine oxidases $A$ and $B$ with Parkinson's disease subgroups. Genomics. 2004;83(3):45460.

92. Costa-Malen P, Costa LG, Checkoway H. Genotype combinations for monoamine oxidase-B intron 13 polymorphism and dopamine $\mathrm{D} 2$ receptor Taq $1 \mathrm{~B}$ polymorphism are associated with ever-smoking status among men. Neurosci Lett. 2005;385(2):158-62.

93. Tochigi M, Suzuki K, Kato C, Otowa T, Hibino H, Umekage T, Kato N, Sasaki T. Association study of monoamine oxidase and catechol-O-methyltransferase genes with smoking behaviors. Pharmacogenet Genomics. 2007;17(10):867-72.

94. Kang SJ, Scott WK, Li YJ, Hauser MA, van der Walt JM, Mayhew GM, West SG, Vance JM, Martin ER. Family-based case-control study of MAO-A and MAO-B polymorphisms in Parkinson's disease. Mov Disord. 2006;21(12):2175-80.

95. Ducci F, Enoch MA, Hodgkinson C, Xu K, Catena M, Robin RW, Goldman D. Interaction between a functional MAO-A locus and children sexual abuse predict alcoholism and anti- 
social personality disorder in adult women. Mol Psychiatry. 2008;13:334-47.

96. Nilsson KW, Wargelius HL, Sjoberg RL, Leppert J, Oreland L. The MAO-A gene, platelet MAO-B activity and psychosocial environment in adolescent female alcohol-related problem behaviour. Drug Alcohol Depend. 2008;93(12):51-62.

97. Saito T, Lachman HM, Diaz L, Hallikainen T, Kauhanen J, Salonen JT, Ryynanen OP, Karvonen MK, Syvalahti E, Pohjalainen T, Hietala J, Tiihonen J. Analysis of monoamine oxidase A (MAO A) promoter polymorphism in Finnish male alcoholics. Psychiatry Res. 2002;109(2):113-9.

98. Contini V, Marques FZ, Garcia CE, Hutz MH, Bau CH. MAO-AuVNTR polymorphysm in a Brazilian sample: further support for the association with impulsive behaviors and alcohol dependence. Am J Med Genet B Neuropsychiatr Genet. 2006;141B:305-8.

99. Wiesbeck GA, Wodarz N, Weijers HG, Dursteler-MacFarland KM, Wurst FM, Walter M, Boening J. A functional polymorphism in the promoter region of the monoamine oxidase A gene is associated with the cigarette smoking quantity in alcohol-dependent heavy smokers. Neuropsychobiology. 2006;53:181-5.

100. Mokrović G, Matošić A, Hranilović D, Štefulj J, Novokmet M, Orešković D, Balija M, Marušić S, Čičin-Šain L. Alcohol dependence and polymorphisms of serotonin-related genes: association studies. Coll Antropol. 2008;32 (Suppl 1):127-31.

Sažetak

\section{NEUROBIOLOŠKE OSNOVE OVISNOSTI O ALKOHOLU}

\section{A. Matošić, S. Marušić, B. Vidrih, A. Kovak Mufíci L. Čičin-Šain}

Ovisnost o alkoholu predstavlja heterogeni psihijatrijski poremećaj po svojoj etiologiji i fenotipu. Razlike u fenotipskim karakteristikama se ogledaju u dobi nastanka ovisnosti, alkohološkoj anamnezi, odnosno povijesti pijenja, komorbidnim poremećajima i nastanku apstinencijskih smetnji. Što se tiče etiologije alkoholizma, smatra se kako bolest nastaje kao posljedica međusobnog djelovanja okruženja i genetskih čimbenika. Brojnim istraživanjima tijekom posljednjih nekoliko desetljeća upoznati su mnogi aspekti biokemijske, stanične i molekularne podloge ovisnosti o alkoholu, što je dovelo do toga da se alkoholizam kao i druge ovisnosti danas smatra moždanom bolesti. Prepoznavanjem alkoholizma kao bolesti koja u svojoj osnovi ima promjene neurobioloških mehanizama, kao i jasnu genetsku podlogu, pretpostavljeno je i da je dijagnoza bazirana samo na simptomatologiji, u osnovi heterogena. Kako bi se pokušao riješiti problem klinički heterogene prirode ovisnosti tijekom proteklih pedesetak godina predložene su različite subklasifikacije bolesnika. Prema Cloningeru podtipovi alkoholizma razlikuju se i s obzirom na promjene u moždanim neurotransmiterskim sustavima pa tako pretpostavlja da bolesnici tipa 1 alkoholizma imaju jače deficitarnu dopaminergičnu transmisiju, dok kod bolesnika tipa 2 alkoholizma dopaminergična transmisija nije znatnije poremećena, ali je prisutan značajan nedostatak serotonergične transmisije. Time je utemeljio tzv. neurobiološki model alkoholizma. Kako razlike u neurotransmisiji povezuje i s razlikama u osobnosti/ crtama ličnosti taj model naziva se i psihobiološki model alkoholizma. Kod tipa 1 alkoholizma prisutna je izražena osobina izbjegavanja štete (HA), smanjena transmisija dopamina i povišena serotoninska transmisija, dok tip 2 alkoholizma ima izraženu osobinu traženja uzbuđenja (NS), nepromijenjenu dopaminsku (DA) transmisiju i smanjenu serotoninsku (5HT) transmisiju. Navedene neurokemijske razlike među podtipovima alkoholizma čine osnovu za drugačiji terapijski pristup bolesnicima. Pijenje alkohola mijenja ekspresiju različitih gena u mozgu čovjeka. Model nasljeđivanja alkoholizma nije jasan, no smatra se da je bolest povezana s većim brojem gena (poligenska) uključenih u neurotransmisiju, stanične mehanizme i opće metaboličke funkcije uz istodobni utjecaj okoliša. Doprinos genetičkih čimbenika jači kod određenih tipova alkoholizma te se posljednjih godina u istraživanjima alkoholizma susreću studije koje istražuju povezanost pojedinog podtipa alkoholizma s pojavom polimorfizama u genima koji kodiraju sinaptičke proteine uključene u nastanak alkoholizma. Primarna uloga monoaminoksidaze (MAO) u mozgu je katalizacija oksidativne deaminacije neurotransmiterskih amina - serotonina, adrenalina, noradrenalina, dopamina, i stoga taj enzim predstavlja ključni čimbenik u održavanju citoplazmatske koncentracije različitih neurotransmitera, odnosno u regulaciji neurotransmiterske sinaptičke aktivnosti. Obzirom na svoju funkciju, MAO je enzim koji je uključen u etiologiju i patogenezu različitih neuropsihijatrijskih i neuroloških bolesti. Nalaz snižene aktivnosti trombocitne MAO-B u različitim psihijatrijskim bolestima doveo je do pretpostavke da taj enzim može biti konstitucijski/genetički pokazatelj (trait marker) ili pokazatelj stanja bolesti (state marker) u biološkoj psihijatriji. Vezano uz ovisnost o alkoholu, postoji više studija koje su istraživale povezanost polimorfizama u genima koji kodiraju MAO i alkoholizma, no one se prvenstveno odnose na VNTR polimorfizam u regulatornoj regiji gena za MAO-A za koji se smatra da utječe na transkripcijsku aktivnost/funkcionalnost enzima.

Ključne riječi : Alkoholizam - genetika; Alkoholizam - patofiziologija; Genetska predispozicija za bolest; Monoamino oksida$z a-k r v ;$ Fenotip; Polimorfizam, genetski 